\title{
Pedagogy in Life-Long Learning in the Perspective of Islam
}

\author{
Aminudin Basir @ Ahmad \\ Mohamad Sabri Haron \\ Zulkifli Mohamad \\ Hamdzun Haron \\ Azizi Umar \\ Azizah Ya'acob \\ Rozmel Abdul Latiff \\ Universiti Kebangsaan Malaysia \\ Email:manhaj@ukm.edu.my
}

Doi:10.5901/ajis.2015.v4n1p51

\section{Abstract}

The Islamic view on life-long learning is not something new. This is explained by the fact that the learning system in Islam has started when one is born until it ends as he or she dies. The onset of the education process is at the initial phase of marriage. In the scope of the surge of globalisation, questions are raised as how best to face this challenge through the lifelong learning. This article elaborates on the pedagogy in lifelong learning and it is discussed in the light of the Islamic perspective. Data and information were obtained via the qualitative method. The content analysis stands out, as the main method used in this work. The study findings are quick to point out that the notion of lifelong learning has long existed in Islam, since the time of the Prophets and Apostles. Al-Quran and al-Sunnah have manifested themselves as the sources of knowledge that are needed by mankind all through their lives to be learned and practised. The analysis outcome also provides evidence that the Prophet, Muhammad s.a.w did explain several significant methods in the pedagogical aspect which is thought to be relevant for application.

Keywords: Pedagogy, Lifelong, Islam

\section{Introduction}

Pedagogy makes up one of the four main components that are crucial in a learning process- teacher, student, subject and pedagogy. The success of learning, upon meeting its objectives is also attributed to the pedagogical factor. Despite it being regarded as facilitative, its significance as the knowledge 'bridge' cannot simply be refuted. An important knowledge cannot be simply be understood and accepted, without the help of an effective pedagogy.

Therefore, as humans of the Caliph status, added to the fact that we are held accountable to guide and lead others, finding knowledge is nothing but compulsory. Without knowledge, our leadership capabilities cannot be properly carried out. It is therefore, very important for one to learn all throughout his or her life, formally or otherwise. Human happiness can only be achieved through the knowledge guidance obtained through learning.

This study aimed to identify the pedagogical methods in life long learning based on Islamic perspective through the analysis of evidences cited in the al-Quran and al-Sunnah. The findings will benefit both educators and learners in seeking knowledge throughout one's lifetime.

\section{Literature Review}

Lifelong learning is interpreted as the effort of seeking for knowledge and the exploration of information done all the time (Self Development, 2011). From the Islamic perspective, one is demanded to be in the quest for knowledge especially the knowledge of fardhu ain. To fulfil the needs of individuals and the society in which they live, the knowledge of fardhu 
kifayah is also of utmost importance. Knowledge knows no boundaries and defeats any limitations. This has been dictated by Allah s.w.t in the Quranic chapter of al-Kahfi, verse 109:

"Say (Dear Muhammad): "If the sea were ink for [writing] the words of my Lord, the sea would be exhausted before the words of my Lord were exhausted, even if We brought the Like of it as a supplement"

The above verse explains about the expansiveness of the Divine knowledge. The sea water is chosen as the analogy, used to resemble the 'pen' used to take note and record knowledge. Even if the sea water dries up and other sea water is brought in to replace it, there is still abundant of the knowledge of Allah s.w.t to be recorded. This accounts for the comparison of how great knowledge can be; how extensive it is. Based upon this reality, Islam proposes that its followers should work hard to seek knowledge and learn.

In the chapter of Luqman, verse 27, Allah further details the broad nature of knowledge:

And if whatever trees upon the earth were pens, and the sea was [ink], repleneished thereafter by seven [more] seas, the words of Allah would not be exhausted. Indeed, Allah is exalted in Might and Wise. According to al-Rabi'lbn Anas, the knowledge of mankind if compared with the knowledge of Allah s.w.t, would be that of a drop of sea water which falls into the entire ocean (Ibn Kathir, 1981).

In line with this reality, then learning should be made a lifelong process for every man, expressed in the phrase " from the time at birth until one dies". There are some other reasons which necessitate the process of lifelong learning to be ongoing in human's life. One of the reasons is the permanence and the truth of the source until the end of time. AlQuran and al-Sunnah themselves are two messengers' sources which are laden and compact with knowledge. Since the advent of Rasulullah s.a.w up until today, al-Quran and al-Sunnah have been subject to constant examination. Various new discoveries have been reported. From another aspect, al-Quran and al-Sunnah remain to be knowledge sources that go far beyond time and human age. The greatness of the two sources is evident from the perspective of faith (aqidah) which illustrates the greatness and supremacy of Allah.

This is especially proven when the Quran explains in detail in several chapters, the issue of embryology, prior to the scientific studies done by Streeter dan O' Rahiliy on the same area in the 20th century (Arip Kasmo, 2006). From the Shari'a viewpoint, the Islamic economic system has stood in prominence as the most ideal Islamic financial system all over the world. Up until today, a lot of new discoveries based on al-Quran and al-Sunnah have been unraveled. This includes the change of water molecule, the speaking ants and many others.

Other reasons include the fact that the human mind will always work and will spark various innovations.

This will encourage people to learn consistently for the purpose of improving humans' lives and their ways of life. The concept of the ISO is one of the best examples in this context. The practice to enhance oneself constantly and to improve life quality, have become two of the major attributes of the Islamic Civilization (KPT, 2009). The change of materials happening to a lot of aspects is also birthed from ongoing learning. The innovation of mobile telecommunication gadgets and computer are two remarkable examples in the world today, as far as this aspect is concerned.

\section{Research Methodology}

This study adopted the qualitative content analysis method in which the content of both al-Quran and al-Hadith were analyzed. Al-Quran and al-Hadith are the the primary sources for the basis of Islamic teaching. This method was selected due to the fact that through the content analysis, the keywords, contexts of the verses in the al-Quran and the concepts in the al-Hadtih related to pedagogy of life long learning would be able to be identified, extracted and analysed qualitatively. This method assists the researcher in making identification of statements in the al-Quran and al-Hadith related to the pedagogical aspects deemed appropriate for this study. The hadiths referenced had been identified as valid or hasan (authentic).

Analysing the content helps the researcher to grasp some pedagogical forms that have been practised, especially from the perspective of Islam. For the analysis, the inductive approach as summed up by Bogdan and Biklen (1982) has been employed.

\section{Findings and Discussion}

\subsection{Pedagogy in lifelong learning}

Pedagogy is defined as an art of teaching that involves the use of teaching methods and techniques. Historically 
speaking, the word 'pedagogy' is derived from a Greek word of 'pedagogue' meaning an educator who has the talent and ability to perform his or her teaching duties effectively (Mok Soon Sang, 1994).

From the stance of the Islamic Aqidah, all Prophets and Apostles are the best educators. They had successfully delivered Allah's commands and teachings, seen in the emergence of pious followers. The Prophet Muhammad s.a.w himself had successfully displayed such a beautiful and effective pedagogy in the process he adopted to teach and educate his people.

1. Showing examples through practice: Rasulullah s.a.w had issued an order: Pray the way you see I pray" (alBukhariy, 2000). The above hadith highlights how Rasulullah s.a.w had become a role model to his brothers and followers, in his teaching of praying properly.

2. Forming diagrams: In this aspect, Abdullah Ibn Mas'ud r.a stated: Rasulullah s.a.w had drawn for us a straight line and then the Prophet said: This is the path of Allah". Then he sketched several other lines on the right and left off the first line and uttered: On these roads, there are evils calling us to them. Then he uttered a dictation from Allah s.w.t which means: .. This is My path, which is straight, so follow it, and do not follow [other] ways, for you will be separated from His way (al-An'am, 153)" (al-Tirmidhiy, 2000 Sahih).

3. Suitable intonations: Al-Irbad Ibn Sariyah stated: Rasulullah s.a.w had given to us a very moving talk, as if it was the last thing he was going to tell us as a will. He stated: I am leaving my will to you to have faith in Allah, succumb to Him and be obedient to Him although he who will give you orders is a slave" (al-Tirmidhiy, of the status of Hasan Sahih, 2000). This illustrates that the Prophet had delivered his speech very effectively that his fellow brothers and followers were moved and overwhelmed. This shows that the Prophet had employed the right intonation in his talks.

4. Starting a conversation with an issue and bringing in true stories: Fatimah binti Qais had narrated this: I prayed together with Rasulullah s.a.w. and I was in the women's section (Saf). Having prayed, the Prophet was sitting at the podium and was laughing, then he said: Everyone should be at their own place." Then he asked: Do you know why I had asked you to gather here? They answered: Only Allah and the Prophet know this. Then he told us about the story of Tamim al-Dariy who was swept away to an island when his ship was hit by a strong wave. In the island he came across a creature named Dajjal" (Muslim, 2000).

5. Showing non-verbal change: Amru Ibn Syu'ib narrated that his grandfather had informed him: One day, my friends and I were attending a knowledge session that had been my favourite. There were several older friends of Rasulullsh s.a.w who were talking about the verses of the Quran near to the Rasulullah's door of his house. We were listening to their discussion until it came to a heated debate. Consequently, Rasulullah s.a.w came out of his house in rage and his face turned red out of fury, and he immediately threw them with sand to ease the debate. He then said: Be patience, my people, this kind of dispute is what made the people before you disintegrate" (Muslim, 2000). The story above shows that Rasulullah s.a.w had displayed his anger by showing a change of facial expression to show how hazardous it is to fight about religious issues. After that, he explained the reason why the earlier people had came to disintegrate.

6. Making a situation an opportunity to educate: Al-Bukhariy (2000) narrated that, Anas Ibn Malik explained how a rural Arabic man had entered a mosque. He had urinated in the mosque. His action was noticed by Rasulullah s.a.w and his friends who happened to be in the mosque. Then they wanted to beat him, but Rasulullah prevented them from doing it and said: "Let him finish his business. Then you take a pail of water and pour it over the place he urinated. You are born not to complicate things but to make it easier". He then approached the man and told him politely: "This mosque is not to be dirtied, it is a place for people to pray, read the al-Quran and humbly praise Allah in zikr". After listening to the advice, the man then prayed:" Dear Allah have a blessing on me and Muhammad and bless no one but ourselves". (Ahmad, 2001). The moral value that can be learned from this educational method is educating and teaching individuals who lack the intelligence or sense of reasoning. It is established that urinating at the mosque is a sin, but Rasulullah was not angry with the man. He was well aware that the man must not know about the rule. After the man had finished urinating, and the place was cleaned, then Rasulullah s.a.w had given an advice well-manneredly and taught him about the position and the nobility of the mosque. The effectiveness of his teaching was proven when the man had prayed for God's blessings for the Prophet.

\subsection{Lifelong learning practice}

The practice of lifelong learning has been mentioned in the al-Quran. The story of the journey of Musa with his assistant 
in their quest for knowledge from Khaidir survives as one of the best examples in this matter. Allah s.w.t had ordered the Prophet Musa to learn with someone knowledgeable. For this purpose, the prophet Musa a.s had undergone several faroff, time-consuming journeys. This is again dictated by Allah in the chapter of al-Kahfi, verse 60:

Finally, Musa and Yusya Ibn Nun had met with the Prophet Khaidir where they had lost their fish supply that had jumped out. Musa had asked for Khaidir's permission to follow him with the aim to gain true knowledge that has been taught by Allah s.w.t (Ibn al-Qayyim,2010).

The fact above shows Musa's attitude, wishing to continuously gain knowledge and learn from other people although he has already held the status of a Prophet to Allah . (al-Khatib al-Baghdadiy, 2009).

Al-Bukhariy narrated further that Umar Ibn al-Khattab r.a had said: My neighbour and I are from the clan of Ansar from the side of Bani Ummayyah Ibn Zaid from a village close to Madinah. We took turns to attend the knowledge session by Rasulullah s.a.w. One day I would go, and the next day he would go. When I returned from the knowledge session, I would be telling him about the messages that I took from Rasulullah s.a.w and other types of knowledge. He would also do the same (2000).

The statement above shows the practice of the brothers in Islam who were always in search of knowledge although in the midst of busy schedules. There is the concept of time management and the practice of wise sharing of knowledge to render the knowledge seeking a success.

The lifelong learning practice was also shown by Jabir Ibn Abdillah r.a. He had heard one of the Prophet's friends Abdullah Ibn Unais to have a hadith that he had not known yet. Thus, to hear the hadith, he had bought a camel and prepared for the journey. After journeying for a month, he had finally reached a place called Syam. After he had reached the home of Abdullah Ibn Unais r.a he had hugged him. Then Jabir Ibn Abdillah said: I would like to listen to the hadith that you had heard from Rasulullah s.a.w, I fear that I will die before I get to listen to it"

Abdullah Ibn Unias stated: I heard Rasulullah s.a.w dictate: In the end of time, Allah s.w.t will gather humans in their naked state. Then Allah s.w.t will urge to them in His words: I am King, I am the Judge (al-Bukhariy, 2000)

Ata Ibn Abi Ribah then told a story. Abu Ayub had gone out to see Uqbah Ibn Amir in Egypt. He wanted to ask Uqabah about a hadith he heard from Rasulullah s.a.w. When Abu Ayub arrived in Egypt he had paid a visit to Maslamh Ibn Mukhallad al-Ansariy. Maslamah was the Governor of Egypt at the time. Abu Ayub explained the purpose of his visit to Egypt, which was to listen to a hadith from ke Uqbah Ibn Amir.

Then Abu Ayyub was assisted by Maslamah to go Uqbah's home. As they arrived, Maslamah's assistant told him that there was a Abu Ayyub who came to visit. As he heard the news, Uqbah immediately came out of his house to see Abu Ayyub then he hugged him close. Afterwards, Abu Ayyub explained why he came and then Uqbah had said:" I heard Rasulullah s.a.w say: Those who shields the humiliation of a Muslim in this world, then Allah will shield his in the afterlife". Upon hearing the hadith, Abu Ayyub then returned to Madinah (Al-Khatib al-Baghdadiy, 2009).

Both events have depicted the patience and hardwork of the brothers towards knowledge. Even though it took such a long time to travel and the cost was high too, they still were determined to obtain knowledge as they realised that it was invaluable.

Not to be missed, in this practice, there is one Tabi'in named Sai'd Ibn al-Musayyab r.h. He used to say that: I spent days travelling just to get one hadith from the Prophet s.a.w (al-Dhahabiy, 1982 ).Qadi al-Fudail Ibn Ghazwan added: "I was sitting in a discussion on the laws of the religion together with Abdullah Ibn Syubrumah, al-Harith Ibn Yazid al-Ukaliy, al-Mughirah Ibn Maqsam al-Dibbiy dan al-Qa'qa Ibn Yazid in the evening. We did not leave the discussion session until we heard the call for the early morning prayer" (al-Darimiy, 2000). This situation suggests an ongoing process of learning. Such strong spirit makes one important trait of lifelong learning.

\subsection{Discussion}

Based on the above findings it is evident that lifelong learning has been stressed by Islam. This is in line with Islam as a complete way of life, which covers every life aspect imaginable. For the purpose of grasping this way of life, al-Quran and al-Sunnah have become the main points of reference. Both these sources are heavily laden with knowledge that every human need in whatever field they embark in. Thus, it needs to be constantly referred to throughout one's lifetime. The contents of both materials also go beyond the test of time and era.

From the Islamic civilization perspective, there is a great deal of clear evidence of Islamic scholars engaging themselves and appreciating this concept of lifelong learning. Their attitude of honouring knowledge and realising the value and significance of knowledge in life has propelled them to literally breathe with the knowledge they sought and gained. Their hardwork has successfully raised the supremacy of Islam and its followers in their respective fields of 
knowledge.

The findings also manage to show that there are several practices applied in the pedagogy shown. This proves that Islam places emphasis on the issue of methods and techniques to ensure the learning can be achieved effectively. Al-Quran and al-Sunnah are not only the primary sources of knowledge through time, but they both also explain the pedagogical methods to ensure that the knowledge gets to be delivered and practised in the right way.

\section{Concluding Remarks}

Lifelong learning is inarguably a demand to fulfil in Islam. It seeks to ensure that man always excels in every endeavour he or she undertakes. There has been clear evidence that shows that Rasulullah s.a.w did practise some effective pedagogical measures in his process of educating his followers; those which are found to be very effective in the process of lifelong learning. Such practises that Rasulullah s.a.w had adopted like using the modelling technique, making sketches, using the 'right' intonation, starting off a conversation with an issue, using non-verbal language and using an opportunity to teach are clear evidences of pedagogical techniques. Further studies on the pedagogy of lifelong learning from the Islamic viewpoints need to be launched as we are confident that there are still a lot more methods to be probed. Pedagogy remains as one of the most important elements which ensure the success of one's lifelong learning.

\section{References}

Al-Quran al-Karim dan Terjemahannya. 1998. Arab Saudi: The Printing of Raja Abdullah Ibn Abdul Azizi. Ahmad Ibn Hanbal. 2001. Musnad al-Imam Ahmad Ibn Hanbal. Beirut: Muassasah al-Risalah.

Bogdan, R.C. \& S.K. Biklen. 1982. Qualitative Research Method for Education. Boston: Allyn \& Bacon, Inc.

Al-Baghdadiy, al-Khatib. 2009. al-Rihlah fi Talab al-Hadith. Halab: al-Maktabah al-Waqfiyyah

Al-Bukhariy, Muhammad Ibn Ismail. 2000. Sahih al-Bukhariy. Riyad: Dar al-Salam

Al-Dhahabiy, Muhammad Ibn Ahmad. 1982. Siyar A'alam al-Nubala'. Beirut: Muassasah al-Risalah.

Al-Darimiy, Abdullah Ibn Abdul Rahman. 2001. Musnad al-Darimiy. Arab Saudi: Dar al-Mughniy.

Ibn Kathir, Ismail Ibn Umar. 1981. Tafsir al-Quran al-Azim. Beirut: Dar al-Fikr

Kementerian Pengajian Tinggi. 2009. Modul Pengajian Tinggi Islam dan Tamadun Asia. Kuala Lumpur: Universiti Malaya.

Muslim, Muslim Ibn al-Hajjaj. 2000. Sahih Muslim. Riyad: Dar al-Salam.

Muhammad Arip Kasmo. 2006. Tamadun Islam dan Tamdun Asia. UKM: Center of General Studies Mok Soon Sang. 1994. Asas

Pedagogi dan Pengajaran dan Pembelajaran. Kuala Lumpur: Kumpulan Budiman.

Center for General Studies. 2011. Modul Pembangunan Diri. UKM: UKM Printing

Ibn al-Qayyim al-Jawziyyah. 2010. Miftah Dar al-Saadah. Halab: al-Maktabah al-Waqfiyyah 
